\title{
ПОНЯТИЕ, ОСНОВНЫЕ ВИДЫ И НАПРАВЛЕНИЯ ПРАВОВОЙ ПОЛИТИКИ В СФЕРЕ ПРАВОВОГО РЕГУЛИРОВАНИЯ ПРОЦЕССОВ МАРГИНАЛИЗАЦИИ
}

\begin{abstract}
Аннотация: В данной статье исследуются вопросы формирования различных направлений правовой политики в сфере минимизачии и преодоления процессов маргинализаџии в российском обществе, негативно влияющих на состояние законности и правопорядка.Автор отмечает, что правовая политика в сфере правового регулирования процессов маргинализаиии - это особый комплексный вид правовой политики государства и иных социальных субъектов, направленный на минимизацию, предупреждение, выявление и устранение негативных маргинальных проявлений в российском обществе. Субъектами такой правовой политики являются органы государственной власти и местного самоуправления Российской Федераиии, общественные объединения и другие некоммерческие организачии, а также личность. Объектами данной сферы правовой политики являются маргинальные субъекты, их права, свободы и обязанности, а также общественные отношения, в которых они участвуют, социальные ценности (общественная безопасность и т.д.), которые оказываются нарушенными в результате негативного воздействия маргинальной среды.

Abstract: This article studies the issues of formation of various directions of legal policy in the sphere of minimization and overcoming marginalization processes in the Russian society, which have a negative influence upon the rule of law and legal order. The author notes that the legal policy in the sphere of legal regulation of marginalization processes is a special complex type of legal policy of the state and other social subjects, which is aimed at the minimization, prevention, revealing and abolishment of negative marginal manifestations in the Russian society. The subjects of such a legal policy are state and municipal bodies of the Russian Federation, non-governmental organizations and other non-commercial organizations, as well as persons. The objects in this sphere of legal policy are marginal subjects, their rights, freedoms and obligations, as well as social relations, in which they participate, social values (social security, etc.), which are violated due to the negative influence of the marginal sphere.
\end{abstract}

Ключевые слова: Маргинальность, соииальная незащищенность, сочиальное неблагополучие, сочиально-адаптационная правовая политика, превентивная правовая политика, маргинальная среда, социальные ценности, личность, субъекты правовой политики, законность.

Keywords: Marginality, lack of social protection, social disadvantage, social adaptation legal policy, preventive legal policy, marginal environment, social values, person, subjects of legal policy, lawfulness.

озможности цивилизационного, стабильного, поступательного развития общества, построение правового и социального государства в России, отсутствие социальных катаклизмов, напрямую зависят от той политики, которую проводит Российская Федерация в сфере обеспечения и защиты прав и свобод личности, от совершенствования механизмов их реализации в правовой и социальной сферах, противодействия росту правонарушений, улучшения качества правотворческой и правоприменительной деятельности.
В контексте общеправовой теории маргинальности как системы полученных и производимых знаний, выдвигаемых гипотез и проблем о негативном влиянии феномена отчужденности, «пограничности» и неадаптивности на состояние законности и правопорядка, в рамках выстраиваемой концепции дифференцируется совокупность рассматриваемых индивидов на социально-незащищенные и социально-неблагополучные, в т.ч. социально-опасные ${ }^{1}$

\footnotetext{
${ }^{1}$ Степаненко Р.Ф. Особенности правового сознания и правовой культуры маргинальной личности // Журнал «Юридическая наука
} 
DOI: $10.7256 / 1811-9018.2014 .4 .11711$

При цитировании этой статьи сноска на доі обязательна

\section{Право и политика 4 (172) • 2014}

группы. Проблемы правовой политики в этой сфере приобретают особую актуальность и значимость. В современной России значительное число людей по тем или иным причинам могут находиться в маргинальной ситуации (положении), утрачивать и вновь приобретать социальный и правовой статус, считаться маргиналами временно или постоянно, иметь определенные черты маргинальных правосознания, правовой культуры и правового поведения.

Согласно данным Российского статистического сборника за 2012 год в Российской Федерации насчитывается примерно пять миллионов безработных, из них один миллион двести тысяч официально зарегистрированы в Центрах занятости населения, при этом официальный прирост безработицы составляет $1,5 \%$ в год. Уровень официальной миграции в России составляет 320 тысяч человек в год, при этом по данным Федеральной миграционной службы нелегальная миграция превышает три миллиона человек. ${ }^{2}$ Примерно восемнадцать миллионов человек или $12,7 \%$ от общего числа населения России имеют денежные доходы ниже величины прожиточного минимума, из них большая часть (около $70 \%$ ) - это экономически активное население, проживающее либо в крупных городах (население более 1 млн. чел.), либо в малых городах (менее 50 тыс. жителей). ${ }^{3}$

Обращение к данным государственной статистики показывает насколько значительно число потенциальных и реальных маргинальных субъектов в современной России. Между тем как показывает практика, постоянно увеличивается число преступлений и иных правонарушений, совершенных маргинальными субъектами, что свидетельствует о возрастающих негативных тенденциях увеличения правовой (юридической) маргинальности, которая характеризуется отчужденностью личности от ценностей права и наоборот, несущей существенную угрозу общественным отношениям, свойственной особенно социально-неблагополучным и социально-опасным маргинальным субъектам. В частности, проводимые нами эмпирические исследования

и практика: Вестник Нижегородской академии МВД России». Нижний Новгород, 2013. - № 24. - С. 25-31.

2 Электронный ресурс Федеральной миграционной службы. Дата обращения 03.08.2013 http://www.fms.gov.ru/press/publications/ news_detail.php?ID=62989.

${ }^{3}$ Российский статистический ежегодник. 2012: Стат.сб./Росстат. P76 М., 2012. - С. 31., Электронный ресурс Федеральной службы государственной статистики. дата обращения 03.08.2013 http:// www.gks.ru/wps/wcm/connect/rosstat_main/rosstat/ru/statistics/ population/level/\#; http://www.gks.ru/free_doc/new_site/population/ urov/urov_53.htm; http://www.gks.ru/free_doc/new_site/population/ urov/urov_52.htm. в этой области лишь подтверждают это положение. Начиная с 2000 по 2010 год, число маргинальных субъектов, совершивших правонарушения, в т.ч. преступления, возросло по Республике Татарстан с 56\% в 2000 г. до 62,4 \% в 2010 году4.

Государство в процессе осуществления своих политических, экономических, социальных, правоохранительных, культурно-воспитательных и иных функций должно проводить правовую политику по предупреждению, выявлению, устранению или минимизации юридической (правовой) маргинальности, а также по реабилитации и социальной адаптации, социальной помощи и поддержки социально-незащищенных маргинальных лиц (групп). Анализ правовой политики, минимизирующей или противодействующей маргинализму в рамках общеправовой теории маргинальности приобретает в этом контексте особую и наиболее ценную актуальность.

Правовая политика государства - это сложное и комплексное явление юридической жизни общества. В юридической науке сформировались различные подходы к пониманию её сущности и основных направлений. Правовая политика как научно-теоретический феномен многомерна, как само право, и проявляет себя в разных измерениях: политическом, правовом, категориальном, деятельностном, доктринальном. Правовая политика, - как отмечает Н.И. Матузов, - один из видов политики как родового интеграционного понятия. ${ }^{5}$ В.А. Рудковский считает, что в современной юридической науке можно выделить три основных подхода к феномену правовой политики: ценностно-нормативный (аксиологический), инструментальный и предметно-функциональный, ${ }^{6}$ что свидетельствует о ее комплексном, всеобщем, интегративном характере для юридической науки и практики. А.В. Малько дает следующее определение: «правовая политика - это научно-обоснованная, последовательная и системная деятельность государственных и негосударственных структур по созданию эффективного механизма правового регулирования ... для формирования правовой государ-

\footnotetext{
${ }^{4}$ Степаненко Р.Ф. Генезис общеправовой теории маргинальности: монография / // Под.ред. д-ра филос. наук, д-ра юрид. наук, проф. О.Ю. Рыбакова - Казань: «Университет управления «ТИСБИ», 2012. - C. 4.

${ }_{5}^{5}$ Матузов Н.И. Актуальные проблемы теории права. Саратов, Изд-во ГОУ ВПО «Саратовская государственная академия права» 2003,. - C. 309-311.

${ }^{6}$ Рудковский В.A. Правовая политика и осуществление права. Волгоград, ВА МВД России, 2009. - С. 125.
} 
ственности и высокого уровня правовой культуры и правовой жизни общества и личности. ${ }^{7}$

Наше исследование правовой политики в сфере предупреждения маргинальности основывается на понимании правовой политики О.Ю. Рыбаковым и представлено тремя наиболее общими подходами: 1) особое сложное социальное явление; 2) комплекс целей, мер, задач, программ, установок; 3) деятельность различных субъектов права. ${ }^{8}$ Из данного положения следует, что правовая политика является, по существу, интегративным и универсальным юридическим средством решения наиболее сложных и резонансных задач эволюционного общественного развития. Правовая политика в сфере защиты прав и свобод личности есть комплекс целей и средств, выраженных в теоретических и практических институтах. Она интегрирует гуманистическое содержание законодательства и разрешает социально-экономическое и политико-правовое противоречия между широкой декларируемостью прав и свобод и низкой степенью их защиты. ${ }^{9}$ В первую очередь, такое направление правовой политики разрабатывается общеправовой теорией маргинальности в сфере защиты конституционных прав и свобод социально-незащищенных слоев населения, к которым мы относим детей-сирот, оставшихся без попечения родителей, детей из неблагополучных семей, нетрудоспособных инвалидов, пенсионеров, безработных, чей денежных доход менее размера прожиточного минимума и др.

Правовая политика в контексте общеправовой теории маргинальности - особый комплексный вид правовой политики государства и иных социальных субъектов, направленный на минимизацию, предупреждение, выявление и устранение маргинальных проявлений в российском обществе. Субъекты такой правовой политики - это органы государственной власти и местного самоуправления Российской Федерации, общественные объединения и другие некоммерческие организации, личность.

Объектами данной сферы правовой политики являются маргинальные субъекты, их права, свободы и обязанности, а также общественные отношения, в

\footnotetext{
7 Правовая политика: словарь и проект концепции / под. ред. А.В. Малько - Саратов, Изд-во ГОУ ВПО «Саратовская государственная академия права», 2010. - с. 26.

${ }^{8}$ См.: Рыбаков О.Ю. Правовая политика как научная теория в историко-правовых исследованиях / Под ред. докт. юрид. наук, докт. философ.наук, проф. О.Ю. Рыбакова. - М.: Статут, 2011. - С. 15.

9 Рыбаков О.Ю. Российская правовая политика в сфере защиты прав и свобод личности: вопросы теории. Автореф. ... докт. юрид. наук. Саратов, 2005. - C. 10.
}

которых они участвуют, социальные ценности (общественная безопасность и т.д.), которые оказываются нарушенными в результате негативного воздействия маргинальной среды.

Антимаргинальная правовая политика (данное операциональное понятие вводится нами для удобства обозначения правовой политики в исследуемой сфере) консолидирует следующие предупредительные (профилактические) меры, направленные на минимизацию маргинальных проявлений в обществе, маргинального правового поведения и маргинального образа жизни:

1) Рациональная, научно обоснованная стратегия и тактика, учитывающая интересы максимально широкого населения;

2) Стабильная и безопасная обстановка в обществе, соблюдение принципов демократии, законности, научности в правотворчестве и правоприменительной деятельности;

3) Совершенствование действующих нормативноправовых актов;

4) Надлежащая реализация существующих нормативных актов. ${ }^{10}$

Воздействие на правовую маргинальность и правовое регулирование процессов маргинализации нацелены на укрепление стабильности и безопасности в обществе, расширение социальной базы государственной политики, формирование социально-правовой государственности и повышение уровня правовой культуры в обществе, становление социального партнерства, увеличение роли институтов гражданского общества и т.д. На наш взгляд, данный комплексный вид правовой политики должен осуществляться в современной России не менее чем в двух направлениях.

Во-первых, это социально-адаптационная правовая политика (регулирующая правовое положение социально-незащищенных групп маргиналов). Целями данного направления правовой политики в сфере предупреждения маргинальных процессов являются: 1) обеспечение и защита прав и свобод человека и гражданина; 2) социально-правовая адаптация и реабилитация социально-незащищенных и социальнонеблагополучных слоев; 3) улучшение их правового и социального положения; 4) повышение уровня образования, в т.Ч. правового; 5) содействие в реализации прав и свобод той части маргиналов, которая не опасна для общества и может принимать участие в решении общегосударственных задач.

\footnotetext{
${ }^{10}$ См.: Нечаева О.В. Правовые аспекты маргинальности. Автореферат дис.. ... канд. юрид. наук. Нижний Новгород. 2006. C. 20
} 
DOI: 10.7256/1811-9018.2014.4.11711

При цитировании этой статьи сноска на доі обязательна

\section{Право и политика 4 (172) • 2014}

Во-вторых, это превентивное направление правовой политики, где государством осуществляется комплекс мер по противодействию маргинальности (здесь имеется ввиду применение мер правового воздействия на социально-неблагополучные, в т.ч. социально-опасные маргинальные группы). В рамках этого направления используется правовое принуждение как основное юридическое средство для укрепления общей дисциплины, законности и правопорядка, что, в свою очередь, влияет на декриминализацию определенных видов маргинального поведения, увеличение правовых норм и предписаний, касающихся правового воздействия на негативные формы маргинального поведения в действующем законодательстве, возможном ужесточении правовых санкций в сфере борьбы с наркотизмом, алкоголизмом и другими формами аддикций, особенно среди молодежи, в запрете пропаганды нетрадиционных сексуальных отношений среди несовершеннолетних и т.п.

В целом, антимаргинальная правовая политика имеет различные уровни обеспечения, придающие процессу её осуществления внутреннее организационное единство и целенаправленность, это:

1) идеологическое обеспечение, выражающееся в социально-правовой пропаганде, просвещении и воспитании (обучении);

2) правовое (разработка и введение в действие законов и подзаконных нормативных актов, направленных на предупреждение и устранение маргинальных явлений);

3) финансовое (планирование, аккумулирование, распределение и использование средств бюджетов различных уровней бюджетной системы Российской Федерации, в том числе федеральных и региональных целевых программ, содействующих решению проблем минимизации правовой маргинальности);

4) организационное (совокупность институтов и учреждений, реализующих данную правовую политику);

5) информационное (поиск, обработка, хранение и использование полной, достоверной, адресной и оперативной правовой информации, необходимой для принятия управленческих решений в области борьбы с деструктивными процессами маргинализации).

Правовая политика в формате общеправовой теории маргинальности характеризуется тем, что имеет комплексный характер, т.е. интегрирует различные виды правовой политики с точки зрения общих целей и задач - борьбы с правовой (юридической) маргинальностью. На наш взгляд, формами и соответствующими им основными направлениями данной сферы правовой политики являются:
1) Субъекты, проводящие правовую политику в сфере минимизации и противодействия маргинальным проявлениям. Здесь выделяются правотворческие, правоприменительные, правозащитные и т.д. органы, учреждения, общественные объединения, граждане;

2) Объекты антимаргинальной правовой политики, содержание разрабатываемых и (или) осуществляемых мер: социально-адаптационное и реабилитационное, ювенальное, образовательное, антинаркотическое, миграционное и т.д. направления.

Правовая маргинальность, а также способы ее проявления выявляются, изучаются и оцениваются с помощью правового мониторинга, ведения правовой статистики, миграционного, профилактического и иного аналогичного учета.

Как отмечалось ранее, согласно пункта 2 Положения «О мониторинге правоприменения», утвержденному Указом Президента Российской Федерации от 20.05.2011 № 657, правовой мониторинг - это комплексная и плановая деятельность, осуществляемая федеральными органами исполнительной власти и органами государственной власти субъектов Российской Федерации в пределах своих полномочий, по сбору, обобщению, анализу и оценке информации для обеспечения принятия (издания), изменения или признания утратившими силу (отмены) законодательных и иных нормативных правовых актов Российской Федерации ${ }^{11}$, без осуществления которого государство не смогло бы обнаружить и зафиксировать количественные и качественные параметры функционирующей в российском обществе юридической маргинальности, планировать и реализовать на практике методы и формы борьбы с таким негативным социально-правовым явлением.

Содержание антимаргинальной правовой политики складывается из таких взаимосвязанных элементов, как стратегия и тактика. Соответственно стратегией являются цели и принципы деятельности государства ${ }^{12}$, ее приоритеты, которые конкретизируются правотворческой антимаргинальной политикой. Тактика правовой политики такого рода конкретизируется в форме правоприменения, поэтому приоритетными ее направлениями, по нашему мнению, являются:

1) оказание социально-психологических, медицинских и иных услуг лицам, находящихся в трудной жизненной ситуации;

\footnotetext{
${ }^{11}$ Собрание законодательства РФ. 2011. № 21. Ст. 2930.

${ }^{12}$ См.: Рудковский В.А. Правовая политика и осуществление права. Волгоград, ВА МВД России, 2009. - С. 210.
} 
2) социальная реабилитация и защита несовершеннолетних;

3) выявление и устранение причин и условий, способствующих безнадзорности и беспризорности несовершеннолетних;

4) трудоустройство экономически активного населения;

5) реабилитация инвалидов для максимально полной их интеграции в общество;

6) осуществление социальной адаптации лиц без определенного места жительства и занятий к условиям жизни в обществе;

7) противодействие распространению алкоголизма, наркотизма в обществе, особенно среди молодежи;

8) осуществление последовательной и сбалансированной миграционной политики и др.

Правотворческая политика в сфере минимизации и противодействия негативным процессам маргинализации осуществляется Президентом РФ, представительными органами власти на общефедеральном и региональном уровнях, органами законодательной, судебной и исполнительной власти, органами местного самоуправления, их должностными лицами. На правотворческом уровне определяются государственные приоритеты в противодействии маргинальности, систематизируются нормативные правовые акты, регулирующие отношения, связанные с негативными проявлениями маргинальности, нормативно закрепляется и развивается комплекс мер по их минимизации, повышается эффективность государственной деятельности по выявлению, предупреждению и устранению причин и условий, обусловливающих увеличение процессов маргинализации.

Однако только правотворческая деятельность представительных и иных органов государственной власти, органов местного самоуправления не является единственной составляющей антимаргинальной правотворческой политики государства. Необходимо создавать условия правотворческой деятельности, определять ее стратегические направления, приоритеты. ${ }^{13}$

Стратегиями правотворческой антимаргинальной политики являются:

- необходимость и достаточность правового обеспечения в сфере выявления и устранения маргинальности;

- прогноз развития маргинальности на основе данных Росстата, профильных министерств и ведомств, социологических опросов;

\footnotetext{
${ }^{13}$ См.: Рыбаков О.Ю. Российская правовая политика в сфере защиты прав и свобод личности: вопросы теории. Автореф. ... докт. юрид. наук. Саратов, 2005. - С. 20.
}

- $\quad$ разработка государственных программ, стратегий по приоритетным направлениям антимаргинальной политики, таким как профилактика безнадзорности несовершеннолетних, сокращение уровня безработицы, например, государственная программа «Содействие занятости населения», принятая на 2013-2020 годы и иные программные документы;

- $\quad$ формирование правовых механизмов реализации маргинальными субъектами прав и свобод человека и гражданина;

- совершенствование нормативно-правовой базы, детальная регламентация практической деятельности учреждений и специалистов, осуществляющих антимаргинальную правовую политику;

- $\quad$ выявление законодательных пробелов и дискриминационных норм, приводящих к утрате или изменению правового статуса, например, к утрате или не приобретению жилья, потере работы и т.п.; - $\quad$ издание «антимаргинализационных» норм права, восстанавливающих социальный и правовой статус субъектов правоотношений и др.

5 декабря 1991 г. в России уголовная и административная ответственность за бродяжничество и попрошайничество были упразднены, ${ }^{14}$ однако в 1996 г. Уголовным кодексом Российской федерации была установлена уголовная ответственность за вовлечение несовершеннолетнего в занятие бродяжничеством или попрошайничеством по статье $151 .{ }^{15}$ Следует учитывать, что данные меры направлены на охрану жизни, здоровья, благополучия несовершеннолетних и, на наш взгляд, именно в этом состоит ценностный аспект данной нормы. А попрошайничество и бродяжничество, признаваемые антиобщественными деяниями, оцениваются законодателем как «свобода выбора» совершеннолетнего маргинального субъекта. Можно констатировать, что в настоящее время, к сожалению, отсутствует полноценный правовой механизм для пресечения бродяжничества и попрошайничества как противоправного поведения. Указ Президента Российской Федерации от 6 февраля 2004 г. отменил Указ от 2 ноября 1993 г.

\footnotetext{
14 Закон «О внесении изменений и дополнений в УК РСФСР, УПК РСФСР и Кодекс РСФСР об административных правонарушениях» // Ведомости Съезда народных депутатов РСФСР и Верховного Совета РСФСР. 1991. № 52, ст. 1074.

${ }^{15}$ В комментарии к УК РФ указано: «Бродяжничество или попрошайничество также нарушают нормальное развитие и формирование личности несовершеннолетнего, препятствуют учебе, развивают паразитические наклонности» (Комментарий к УК РФ / под ред. Ю.И. Скуратова и В.М. Лебедева М.: Изд-во Инфра, 1996. - С. 323.
} 


\section{Право и политика 4 (172) $\bullet 2014$}

«О мерах по предупреждению бродяжничества и попрошайничества», создававший правовую основу для принудительного временного содержания этих лиц в приемниках-распределителях. Однако, в настоящее время законодателями четырех субъектов Российской Федерации предприняты попытки, как уже отмечалось ранее, введения административной ответственности за данные виды маргинального поведения (Москва, Республика Татарстан, Краснодарский край, Чувашская Республика)

Закрепление в ст. 37 Конституции Российской Федерации запрета принудительного труда, а также принятие Федерального закона № 54-Ф3 от 30 марта 1998 года «О ратификации Конвенции о защите прав человека и основных свобод и Протоколов к ней» ${ }^{16}$, кардинальным образом изменили стратегию государства в отношении поведения маргинальных субъектов, с последующим внесением соответствующих изменений в законодательство Российской Федерации и её субъектов. Приоритетным направлением деятельности государства в этой сфере стало оказание социальной помощи маргиналам, оказавшимся в сложной жизненной ситуации.

8 июня 1996 г. Правительство РФ приняло Постановление «Об утверждении Примерного положения об учреждениях социальной помощи для лиц без определенного места жительства и занятий» ${ }^{17}$ (в развитие постановления Правительства РФ от 5 ноября 1995 г. № 1105 «О мерах по развитию сети учреждений социальной помощи для лиц, оказавшихся в экстремальных условиях без определенного места жительства и занятий» ${ }^{18}$ ).

Кроме того, государство осуществляет правовую политику в отношении иных субъектов, правовой статус которых может быть охарактеризован как маргинальный.

Основные направления государственной политики в сфере занятости населения закреплены в Законе РФ от 19 апреля 1991 г. № 1032-1 «О занятости населения в Российской Федерации», положения которого конкретизированы в ряде законов и подзаконных нормативных правовых актов. На базе этого закона разработана и введена в действие государственная программа «Содействие занятости населения (2013 - 2020 гг.)». Во исполнение данной государственной программы Правительство РФ издало ряд распоряжений, которые

\footnotetext{
${ }^{16}$ Собрание законодательства РФ, 06.04.1998, N 14, ст. 1514

17 Российская газета, 1996. 18 июля.

18 Собрание законодательства Российской Федерации. 1995. № 46 , ст. 4454 .
}

детализируют и развивают основные положения законодательства о труде. ${ }^{19}$

Постановление Правительства РФ от 7 сентября 2012 г. № 891 «О порядке регистрации граждан в целях поиска подходящей работы, регистрации безработных граждан и требованиях к подбору подходящей работы» направлено на регламентацию оказания государственных услуг в сфере содействия занятости, устанавливает порядок, сроки и результаты оказания государственной услуги, что способствует сокращению правовой маргинальности среди этой категории субъектов права. Важным является и определение критериев подходящей работы, которая должна соответствовать профессиональной подготовке, условиям последнего места работы, состоянию здоровья соискателя и транспортной доступности рабочего места. Кроме того, Постановлением определены категории безработных, которым можно предлагать общественные работы и работу временного характера.

В январе 2013 года Приказ Минтруда России ${ }^{20}$, утвердив стандарты оказания государственных услуг нетрудоустроенным гражданам, конкретизировал и обеспечил необходимую и достаточную нормативную базу оказания социально-психологической помощи безработным. Она заключается в социальной адаптации соискателей силами служб занятости, которая предполагает индивидуальный анализ причин, вызывающих трудности в поиске работы, а также обучение технологиям поиска работы, составления резюме, прохождения собеседования с работодателем (в том числе в форме тренингов) и т.п. Данный приказ также обеспечил реализацию нормы статьи 7.1-1 Закона о занятости о получении безработными гражданами бесплатной психологической поддержки.

Еще одним своим приказом ${ }^{21}$ Минтруд России конкретизировал информационное обеспечение правовой

\footnotetext{
19 Распоряжение Правительства РФ от 22 ноября 2012 г. № 2149-р, Распоряжение Правительства РФ от 19 июня 2013 г. № 1000-p, приказ Минтруда России от 26 июня 2013 г. № 280 “Об утверждении детального плана-графика реализации государственной программы Российской Федерации “Содействие занятости населения” на 2013 год и плановый период 2014-2015 годов”). //

20 Приказ Минтруда России от 9 января 2013 г. № 3н «Об утверждении федерального государственного стандарта государственной услуги по социальной адаптации безработных граждан на рынке труда» // .

21 Приказ Минтруда России от 22 февраля 2013 г. № 74н «Об утверждении Административного регламента предоставления Министерством труда и социальной защиты Российской Федерации государственной услуги по информированию граждан и работодателей о положении на рынке труда в Российской Федерации, правах и гарантиях в области занятости населения и защиты от безработицы» //
} 
политики в сфере содействия занятости населения, которая с точки целей и задач может считаться, в том числе, и антимаргинальной правовой политикой. Был уточнен порядок информирования о состоянии рынка труда, правах в области занятости и защиты от безработицы, перечень наиболее востребованных профессий с указанием средней зарплаты. Эти сведения размещаются на официальном сайте ведомства, предоставляются по заявлению гражданина (в том числе иностранного гражданина или лица без гражданства).

В числе основных направлений программы «Содействие занятости населения на период 2013 - 2020 гг.» необходимо отметить дифференцированную политику использования труда мигрантов, что признается наиболее проблемным и важным для осуществления взвешенной правовой политики в отношении данной категории индивидов (страт), оказавшихся в маргинальном положении (ситуации). Согласно данным Росстата многие работодатели предпочитают нанимать на работу трудовых мигрантов, чей труд традиционно оплачивается ниже, чем труд граждан России, что, естественно, способствует росту безработицы среди российского населения. Половина россиян считают, что мигранты лишают их рабочих мест ${ }^{22}$. Законодатель постоянно восполняет правовые пробелы, позволяющие принимать на работу мигрантов в обход требований трудового законодательства, уточняются и даже ужесточаются требования к мигрантам, порядок пребывания мигрантов на территории России. Однако полностью отказаться от использования труда мигрантов невозможно и ежегодно Правительство РФ регулирует квоты использования труда мигрантов по регионам России.

Россия является участником значительного числа международных договоров и соглашений, регулирующих на международно-правовом уровне правовой статус беженцев, вынужденных переселенцев, иностранных граждан, лиц без гражданства.

Федеральный закон от 19 февраля 1993 г. N 4528-I «О беженцах» определил правовой статус беженцев, членов их семей, развивая при этом положения Конвенции о статусе беженцев (Женева, 28 июля 1951 г.). ${ }^{23}$ Беженец - это лицо, которое не является гражданином Российской Федерации и которое в силу вполне обоснованных опасений стать жертвой преследований по признаку расы, вероисповедания, гражданства, национальности, принадлежности к определенной социаль-

\footnotetext{
22 Электронный ресурс Фонда Общественное мнение http://fom.ru/obshchestvo/10484

${ }^{23}$ Гражданин и право. 2002, № 6. - С. 121.
}

ной группе или политических убеждений находится вне страны своей гражданской принадлежности и не может пользоваться защитой этой страны или не желает пользоваться такой защитой вследствие таких опасений; или, не имея определенного гражданства и находясь вне страны своего прежнего обычного местожительства в результате подобных событий, не может или не желает вернуться в нее вследствие таких опасений. Принятие закона о беженцах было особенно актуально в начале 1993 года, когда, в результате распада СССР многие его граждане оказались в положении политических либо культурных маргиналов и были вынуждены покинуть место постоянного проживания и приехать на территорию России. Именно поэтому государством проводится активная правотворческая антимаргинальная правовая политика в этой сфере, принимается комплекс правовых актов, регулирующих правовой статус беженцев и вынужденных переселенцев, иностранных граждан и лиц без гражданства.

Закон РФ от 19 февраля 1993 г. N 4530-I «О вынужденных переселенцах» ${ }^{24}$ устанавливает экономические, социальные и правовые гарантии защиты их прав и законных интересов на территории Российской Федерации. Основной комплекс нормативных правовых актов, регулирующих правовой статус беженцев и вынужденных переселенцев и конкретизирующие их постановления и распоряжения федеральных и региональных органов исполнительной власти были приняты в течение 1993 - 2003 гг. Однако в последующие десять лет поток беженцев и вынужденных переселенцев сократился незначительно. В последнее время эти тенденции видоизменяются и число пребывающих в Россию граждан вновь увеличивается.

Действительно, основной проблемой, с которой сталкивается Российская Федерация - это постоянно возрастающее количество мигрантов, определенная часть которых относится к социально-опасному слою маргинальных субъектов. Основным уполномоченным органом в этой сфере является Федеральная миграционная служба Российской Федерации (далее - ФМС России). ФМС России является федеральным органом исполнительной власти, осуществляющим функции по выработке и реализации государственной политики и нормативно-правовому регулированию в сфере миграции, правоприменительные функции, функции по федеральному государственному контролю (надзору) и предоставлению (исполнению) государственных

\footnotetext{
${ }^{24}$ Ведомости Съезда народных депутатов и Верховного Совета Российской Федерации от 25 марта 1993 г. № 12. Ст. 427.
} 


\section{Право и политика 4 (172) 2014}

услуг (функций) в сфере миграции. ${ }^{25}$ ФМС России издает приказы, распоряжения, инструкции, осуществляя непосредственным образом правотворческую антимаргинальную политику государства. Примером этому является Приказы ФМС России, утверждающие административные регламенты предоставления государственных услуг по предоставлению статуса беженца, вынужденного переселенца, по предоставлению политического убежища иностранным гражданам и лицам без гражданства. ${ }^{26}$

Другим Приказом ФМС России ${ }^{27}$ определено, что на семью вынужденного переселенца формируются учетная карточка и личное дело. ${ }^{28}$ C 15 января 2007 года действует Федеральный закон Российской Федерации от 18 июля 2006 г. N 109-Ф3 «О миграционном учете иностранных граждан и лиц без гражданства в Российской Федерации», который, будучи формой государственного регулирования миграционных процессов, является средством осуществления антимаргинальной правовой политики путем обеспечения и исполнения установленных Конституцией Российской Федерации гарантий соблюдения права каждого, кто законно находится на территории Российской Федерации, а также на реализацию национальных интересов Российской Федерации в сфере миграции. ${ }^{29}$

Российская Федерация в рамках Единого экономического пространства заключила Соглашение о правовом статусе трудящихся-мигрантов и членов

\footnotetext{
${ }^{25}$ Положение о Федеральной миграционной службе (утв. постанов лением Правительства РФ от 13 июля 2012 г. N 711)// "Российская газета" от 20 июля 2012 г. N 165

${ }^{26}$ Приказ ФМС России от 29 июня 2012 г. N 218 «Об утверждении Административного регламента предоставления Федеральной миграционной службой государственной услуги по предоставлению статуса вынужденного переселенца и продлению срока его действия»// Российская газета от 21 ноября 2012 г. N 268,

Приказ ФМС России от 5 декабря 2007 г. N 452 «Об утверждении Административного регламента ФМС России по исполнению государственной функции по исполнению законодательства РФ о беженцах»

Приказ ФМС России от 5 декабря 2007 г. N 451 «Об утверждении Административного регламента ФМС России по исполнению государственной функции по исполнению законодательства РФ по предоставлению политического убежища иностранным гражданам и лицам без гражданства»

27 Приказ ФМС России от 13.05.2013 № 235 «Об организации деятельности территориальных органов ФМС России по принятию решения о лишении статуса вынужденного переселенца, по учету вынужденных переселенцев, а также в случаях утраты статуса вынужденного переселенца» // Российская газета". 2013. 07 августа. №172.

28 “Российская газета". 2013. 07 августа. №172.

${ }^{29}$ См. Российская газета 20 июля 2006 г.
}

их семей, а также Соглашение о сотрудничестве по противодействию нелегальной трудовой миграции из третьих государств с Правительствами Республики Казахстан и Республики Беларусь, согласно которому трудящимся-мигрантам не требуется получения разрешений на осуществление трудовой деятельности на территориях государств, срок временного пребывания трудящегося-мигранта и членов его семьи определяется сроком действия трудового договора трудящегося-мигранта с работодателем. ${ }^{30}$

Однако правовая политика в виде преференций трудящимся-мигрантам из Казахстана и Беларуси не распространяется на мигрантов из других государств и апатридов, которые относятся к социально-неблагополучным и социально-опасным маргинальным группам. В этом случае стратегическим направлением правовой политики является ужесточение законодательства в сфере миграции как по отношению к самим мигрантам, так и к организациям, использующим их труд. В начале 2013 года вступил в силу закон, обеспечивающий мигрантам ${ }^{31}$ социально-бытовые гарантии и устанавливающий административную ответственность за непринятие мер по их материальному, медицинскому и жилищному обеспечению, что соответствует общепризнанным принципам и нормам международного права: гуманизм, запрет на принудительный труд, право на достоинство личности.

Однако были внесены изменения в Уголовный кодекс РФ, направленные на усиление уголовной ответственности за организацию незаконной миграции. Данный вид преступления включает незаконный въезд, пребывание либо транзит через РФ иностранных граждан и лиц без гражданства. Внесенные в статью 322.1 УК РФ поправки предусматривают отнесение указанного деяния к преступлениям средней тяжести, а при наличии квалифицирующих признаков - к тяжким преступлениям, и соответственно, увеличение размеров и сроков наказаний. ${ }^{32}$ В частности, подписанные Президентом поправки в закон о порядке выезда и въезда в РФ предусматривают введение трехлетнего запрета

\footnotetext{
30 Федеральный закон Российской Федерации от 11 июля 2011 г. N 186-Ф3 «О ратификации Соглашения о правовом статусе трудящихся-мигрантов и членов их семей»// Российская газета 15 июля 2011 г.

${ }^{31}$ Федеральный закон «О внесении изменений в федеральный закон «О правовом положении иностранных граждан в Российской Федерации» и статьи 18.9 и 28.3 Кодекса Российской Федерации об административных правонарушениях» от 30.12.2012 № 315-Ф3 // Собрание законодательства РФ». 31.12.2012. № 53 (ч. 1). Ст. 7640.

32 Федеральный закон «О внесении изменений в статью 322.1 Уголовного кодекса Российской Федерации»//Собрание законодательства РФ”. 31.12.2012. N 53 (ч. 1). Ст. 7633.
} 
на въезд в страну для иностранцев, ранее нарушивших порядок пребывания в России. ${ }^{33}$ По мнению властей, это позволит усовершенствовать миграционное законодательство и повысить эффективность мер по противодействию незаконной миграции. Таким образом, данные меры будут способствовать укреплению правопорядка в обществе и национальной безопасности РФ.

Федеральный закон от 23 июля 2013 г. N 207-Ф3 «О внесении изменений в отдельные законодательные акты Российской Федерации в целях совершенствования миграционного законодательства и ответственности за его нарушение» ужесточает миграционное законодательство. Вводится безусловный запрет на въезд в Россию иностранцам и апатридам, если они представили подложные документы, а также в период предыдущего визита не заплатили налоги, штрафы или не возместили расходы по их выдворению. Согласно поправкам не могут получить разрешение на работу в нашей стране иностранцы, которые в течение 10 предшествующих лет неоднократно выдворялись из России. Законом усилена административная ответственность за правонарушения в области миграции, а также был расширен перечень нарушений, за которые иностранцев будут безоговорочно и принудительно выдворять из России, в особенности, если трудовые мигранты повторно задержаны за осуществлении трудовой деятельности без разрешения на работу. Кроме того, законом вводятся повышенные штрафы за повторные нарушения миграционного законодательства, особенно в Москве, Санкт-Петербурге, Московской и Ленинградской областях, назначаемые судом.

Приоритетом миграционной политики является также введение дополнительных санкций для работодателей, нарушающих миграционное законодательство. Законом установлен минимальный срок административного приостановления деятельности, вводится ответственность работодателей (заказчиков), за нарушение порядка уведомления миграционных органов о работе указанных лиц, решается вопрос о введении уголовной ответственности для работодателей, использующих труд нелегальных мигрантов.

Российская Федерация в силу принятых на себя международных обязательств регулирует правовой статус мигрантов путем принятия соответствующих законов и иных нормативных правовых актов, осуществляя тем самым правотворческую антимаргинальную правовую политику.

\footnotetext{
${ }^{33}$ Федеральный закон «О внесении изменений в отдельные законодательные акты Российской Федерации» от 23.07.2013 № 224-Ф3 // Российская газета. 2013. 25.07. № 161.
}

Исследовательский интерес к проблеме другого вида правоприменительной политики в сфере противодействия маргинальности обусловлен комплексом причин. Во-первых, это процессы становления гражданского общества в России, во-вторых, гуманизация российской правоприменительной деятельности, ее нацеленность на защиту прав и свобод человека и гражданина, уважение прав человека, в-третьих, это государственные стратегии, целью которых является оказание социальнопсихологической и правовой помощи широкому кругу субъектов общественных отношений, в том числе и маргинальным субъектам, что потребовало разработки соответствующей этим направлениям государственной деятельности антимаргинальной правовой политики.

Анализ правоприменительной правовой политики в исследуемой сфере на теоретическом уровне основывается на достижениях российской юридической науки. Правоприменительная политика, как указывает профессор Н.Н. Вопленко, есть относительно обособленное политико-правовое явление, фокусирующее в себе основные тенденции теории и практики правоприменительной деятельности. ${ }^{34}$ Правоприменительная политика - это выраженная в системе политико-правовых установок, организационно-управленческих средств и тенденций правоприменительной деятельности стратегия и тактика государства в сфере реализации юридических норм. ${ }^{35}$

О.Ю. Рыбаков уточняет понимание правоприменительной политики с точки зрения ее субъектного состава. Правоприменительная правовая политика в сфере защиты прав и свобод личности персонифицируется в двух аспектах. Во-первых, речь идет о субъекте правоприменения - лице, обладающем по действующему законодательству возможностью правоприменения. Во-вторых, каждый акт применения права затрагивает прямо или опосредованно личность, ее права и обязанности, правовой статус, порой и судьбу. В этом смысле рассматриваемая форма правовой политики носит личностно выраженный характер. Однако персонифицированный

\footnotetext{
${ }^{34}$ См.: Вопленко Н.Н. Правоприменительная политика: понятие и содержание // Тезисы докладов IX научной конференции профессорско-преподавательского состава и XII научной студенческой конференции (20-25 апреля 1992 г.). Волгоград, 1992. C. $96-97$

${ }^{35}$ См.: Рудковский В.А. Правовая политика и осуществление права. Волгоград, ВА МВД России, 2009. - С. 288.
} 


\section{Право и политика $4(172) \cdot 2014$}

уровень правоприменительной формы не игнорирует ее общественной значимости, ${ }^{36}$ и, безусловно, оказывает влияние на проведение антимаргинальной правовой полтитики.

Правоприменительная антимаргинальная политика - это организационно-властная деятельность уполномоченных органов и должностных лиц по предупреждению, пресечению маргинальных проявлений, применению правовых санкций и иных юридических мер принудительного характера в ходе рассмотрения и разрешения юридических дел. Целью этого вида правовой политики в сфере пресечения правовой маргинальности является повышение точности и эффективности реализации правовых предписаний всеми субъектами общественных отношений, как субъектами, осуществляющими правоприменительную деятельность (должностные лица и органы исполнительной и судебной власти), а также, непосредственно, и, маргинальными субъектами. Правоприменительная политика в этой области осуществляется, прежде всего, в форме обзоров и обобщений судебной, административной практики, рассмотрения и разрешения конкретных юридических дел с участием маргинальных субъектов. Кроме того, общеправовая теория маргинальности выделяет правозащитную, социально-реабилитационную, в т.ч. ювенальную правовую политику, задачей которых должны стать оказание помощи и содействия лицам, находящимся в маргинальном положении (ситуации)

Таким образом, правовая политика в сфере правового регулирования процессов маргинализации это особый комплексный вид правовой политики государства и иных социальных субъектов, направленный на минимизацию, предупреждение, выявление и устранение негативных маргинальных проявлений в российском обществе. Субъекты такой правовой политики - это органы государственной власти и местного самоуправления Российской Федерации, общественные объединения и другие некоммерческие организации, личность.

Объектами данной сферы правовой политики являются маргинальные субъекты, их права, свободы и обязанности, а также общественные отношения, в которых они участвуют, социальные ценности (общественная безопасность и т.д.), которые оказываются нарушенными в результате негативного воздействия маргинальной среды.

${ }^{36}$ См.: Рыбаков О.Ю. Российская правовая политика в сфере защиты прав и свобод личности: вопросы теории. Автореф. ... докт. юрид. наук. Саратов, 2005. - С. 20.

\section{Библиография:}

1. Вопленко Н.Н. Правоприменительная политика: понятие и содержание // Тезисы докладов IX научной конференции профессорско-преподавательского состава и XII научной студенческой конференции (20 - 25 апреля 1992 г.). Волгоград, 1992.

2. Матузов Н.И. Актуальные проблемы теории права. - Саратов, Изд-во ГОУ ВПО «Саратовская государственная академия права», 2003.

3. Нечаева О.В. Правовые аспекты маргинальности. - Автореферат дис.. ... канд. юрид. наук. Нижний Новгород. 2006.

4. Правовая политика: словарь и проект концепции / под. ред. А.В. Малько - Саратов, Изд-во ГОУ ВПО «Саратовская государственная академия права», 2010.

5. Рудковский В.А. Правовая политика и осуществление права. - Волгоград, МВД России, 2009.

6. Рыбаков О.Ю. Правовая политика как научная теория в историко-правовых исследованиях / Под ред. докт. юрид. наук, докт. философ.наук, проф. О.Ю. Рыбакова. - М.: Статут, 2011.

7. Рыбаков О.Ю. Российская правовая политика в сфере защиты прав и свобод личности: вопросы теории. Автореф. ... докт. юрид. наук. Саратов, 2005.

8. Степаненко Р.Ф . Генезис общеправовой теории маргинальности: монография // Под.ред. д-ра филос. наук, д-ра юрид. наук, проф. О.Ю. Рыбакова Казань: «Университет управления «ТИСБИ», 2012.

9. Степаненко Р.Ф. Особенности правового сознания и правовой культуры маргинальной личности // Журнал «Юридическая наука и практика: Вестник Нижегородской академии МВД России». - Нижний Новгород, 2013.-№ 24. - С. 25-31.

10. В.М. Розин. Секс и любовь в сети или две противоположные личности маргинала современности // Психология и Психотехника. - 2013. - № 1. - C. 104-107. DOI: 10.7256/ 2070-8955.2013.01.2.

11. М.Ю. Барбашин. «Советскость» в этносоциальном пространстве: этнические и институциональные процессы // Политика и Общество. - 2013. - № 3. - C. 104-107. DOI: 10.7256/1812-8696.2013.03.14.

12. А.М. Вафин. Политическая маргинальность: к проблеме типологии политического лидерства // Психология и Психотехника. - 2013. - № 9. - С. 104107. DOI: 10.7256/2070-8955.2013.9.8740.

13. Киреева Н.В.. Типология интеграционных связей // Политика и Общество. - 2014. - № 2. - С. 104-107. DOI: $10.7256 / 1812-8696.2014 .2 .9789$. 
DOI: $10.7256 / 1811-9018.2014 .4 .11711$

При цитировании этой статьи сноска на doi обязательна

Человек и государство

14. Киреева Н.В.. Механизм образования интеграционных связей // Политика и Общество. - 2014. - № 1. - C. 104-107. DOI: 10.7256/1812-8696.2014.1.9788.

15. Терентьева Г. В.. Новый Глобальный подход ЕС к миграции и мобильности (GAMM) и социальные аспекты миграционной политики Италии // Тренды и управление. - 2013. - № 3. - C. 104-107. DOI: 10.7256/2307-9118.2013.3.6592.

16. А.И Кириллова. Интеграция мигрантов-мусульман в российское общество // Тренды и управление. - 2013. - № 2. - C. 104-107. DOI: 10.7256/23079118.2013.2.5009.

17. Полтораков А.Ю.. Проблема двойного гражданства как политико-правовой вызов социогуманитарной безопасности // Право и политика. - 2013. - № 8. C. 104-107. DOI: 10.7256/1811-9018.2013.8.2358.

18. А.Ю. Бельянинов. Политическая и социально-экономическая роль России в интеграционном процессе на постсоветском пространстве // Политика и Общество. - 2013. - № 5. - C. 104-107. DOI: 10.7256/1812-8696.2013.05.8.

19. В.В. Насонкин. Политика и практика ведущих зарубежных стран по привлечению иностранных граждан на обучение // Политика и Общество. - 2013. - № 3. - C. 104-107. DOI: 10.7256/18128696.2013.03.3.

20. О.А. Полюшкевич, Л.Л. Антонова. Интеллигенция в России: условия трансформации // Политика и Общество. - 2013. - № 1. - С. 104-107. DOI: 10.7256/1812 - 8696.2013.01.10.

21. С.Ф. Ударцев. Эволюция идеи европейского единства и опыт ее реализации в моделях государственного устройства // Право и политика. -2012. - № 11. - С. 104-107.

22. О.И. Ставцева. Диалог культур на фоне кризиса мультикультурализма // Философия и культура. 2012. - № 9. - С. 104-107.

23. Г. Г. Ершова. Антропосистема: коммуникативные модели и регулируемая интеграция // Исторический журнал: научные исследования. 2012. - № 4. - С. 104-107.

24. В.Ц. Худавердян. Национальные меньшинства и иммигранты в системе социальных отношений: социально-философское измерение // Философия и культура. - 2012. - № 7. - С. 104-107.

25. Е. А. Попов. Этническая идентификация в обществе посредством языка // Политика и Общество. - 2012. - № 3. - С. 104-107

26. Щупленков Н.О., Щупленков О.В. Особенности развития политико-правовой ориентации соци- ал-демократического движения в России // NB: Исторические исследования. -2014. -2. - С. 22 - 77. DOI: 10.7256/2306-420X.2014.2.10668. URL: http:// www.e-notabene.ru/hr/article_10668.html

27. Гарифуллина Э.Ф. Развитие человеческого капитала как инновационное направление государственной политики // NB: Экономика, тренды и управление. - 2014. - 2. - С. 36 - 43. DOI: 10.7256/23064595.2014.2.4544. URL: http://www.e-notabene.ru/etc/ article_4544.html

28. Белковец Л.П. Иностранцы в Советской России (CССР): регулирование правового положения и порядка пребывания (1917 - 1939-е гг.) Первая часть. // NB: Вопросы права и политики. - 2013. - 5. C. 296 - 350. DOI: 10.7256/2305-9699.2013.5.796. URL: http://www.e-notabene.ru/lr/article_796.html

29. Белковец Л.П. Иностранцы в Советской России (СССР): регулирование правового положения и порядка пребывания (1917 - 1939-е гг.) Вторая часть. // NB: Вопросы права и политики. - 2013. - 6. C. 220 - 284. DOI: 10.7256/2305-9699.2013.6.808. URL: http://www.e-notabene.ru/lr/article_808.html

\section{References (transliteration):}

1. Voplenko N.N. Pravoprimenitel'naya politika: ponyatie i soderzhanie // Tezisy dokladov IX nauchnoi konferentsii professorsko-prepodavatel'skogo sostava i XII nauchnoi studencheskoi konferentsii (20 - 25 aprelya 1992 g.). Volgograd, 1992.

2. Matuzov N.I. Aktual'nye problemy teorii prava. Saratov, Izd-vo GOU VPO «Saratovskaya gosudarstvennaya akademiya prava», 2003.

3. Nechaeva O.V. Pravovye aspekty marginal'nosti. - Avtoreferat dis.. ... kand. yurid. nauk. Nizhnii Novgorod. 2006.

4. Rudkovskii V.A. Pravovaya politika i osushchestvlenie prava. - Volgograd, MVD Rossii, 2009.

5. Rybakov O.Yu. Pravovaya politika kak nauchnaya teoriya $\mathrm{v}$ istoriko-pravovykh issledovaniyakh / Pod red. dokt. yurid. nauk, dokt. filosof.nauk, prof. O.Yu. Rybakova. - M.: Statut, 2011.

6. Rybakov O.Yu. Rossiiskaya pravovaya politika v sfere zashchity prav i svobod lichnosti: voprosy teorii. Avtoref. ... dokt. yurid. nauk. Saratov, 2005.

7. Stepanenko R.F . Genezis obshchepravovoi teorii marginal'nosti: monografiya // Pod.red. d-ra filos. nauk, d-ra yurid. nauk, prof. O.Yu. Rybakova-Kazan': «Universitet upravleniya «TISBI», 2012. 
DOI: $10.7256 / 1811-9018.2014 .4 .11711$

При цитировании этой статьи сноска на dоі обязательна

\section{Право и политика 4 (172) • 2014}

8. Stepanenko R.F. Osobennosti pravovogo soznaniya i pravovoi kul'tury marginal'noi lichnosti // Zhurnal «Yuridicheskaya nauka i praktika: Vestnik Nizhegorodskoi akademii MVD Rossii». - Nizhnii Novgorod, 2013.-№ 24. - S. 25-31.

9. V.M. Rozin. Seks i lyubov' v seti ili dve protivopolozhnye lichnosti marginala sovremennosti // Psikhologiya i Psikhotekhnika. - 2013. - № 1. - S. 104-107. DOI: 10.7256/2070-8955.2013.01.2.

10. M.Yu. Barbashin. «Sovetskost'»v etnosotsial'nom prostranstve: etnicheskie i institutsional'nye protsessy // Politika i Obshchestvo. - 2013. - № 3. - S. 104-107. DOI: 10.7256/1812-8696.2013.03.14.

11. A.M. Vafin. Politicheskaya marginal'nost': k probleme tipologii politicheskogo liderstva // Psikhologiya i Psikhotekhnika. - 2013. - № 9. - S. 104-107. DOI: 10.7256/2070-8955.2013.9.8740.

12. Kireeva N.V.. Tipologiya integratsionnykh svyazei // Politika i Obshchestvo. - 2014. - № 2. - S. 104-107. DOI: 10.7256/1812-8696.2014.2.9789.

13. Kireeva N.V.. Mekhanizm obrazovaniya integratsionnykh svyazei // Politika i Obshchestvo. - 2014. - № 1. - S. 104107. DOI: 10.7256/1812-8696.2014.1.9788.

14. Terent'eva G. V.. Novyi Global'nyi podkhod ES k migratsii i mobil'nosti (GAMM) i sotsial'nye aspekty migratsionnoi politiki Italii // Trendy i upravlenie. - 2013. - № 3. - S. 104-107. DOI: 10.7256/23079118.2013.3.6592.

15. A.I Kirillova. Integratsiya migrantov-musul'man v rossiiskoe obshchestvo // Trendy i upravlenie. - 2013. - № 2 . - S. 104-107. DOI: 10.7256/2307-9118.2013.2.5009.

16. Poltorakov A.Yu.. Problema dvoinogo grazhdanstva kak politiko-pravovoi vyzov sotsiogumanitarnoi bezopasnosti // Pravo i politika. - 2013. - № 8. - S. 104-107. DOI: 10.7256/1811-9018.2013.8.2358.

17. A.Yu. Bel'yaninov. Politicheskaya i sotsial'noekonomicheskaya rol' Rossii v integratsionnom protsesse na postsovetskom prostranstve // Politika i Obshchestvo. - 2013. - № 5. - S. 104-107. DOI: 10.7256/1812-8696.2013.05.8.

18. V.V. Nasonkin. Politika i praktika vedushchikh zarubezhnykh stran po privlecheniyu inostrannykh grazhdan na obuchenie // Politika i Obshchestvo. - 2013. № 3. - S. 104-107. DOI: 10.7256/1812-8696.2013.03.3.

19. O.A. Polyushkevich, L.L. Antonova. Intelligentsiya v Rossii: usloviya transformatsii // Politika i Obshchestvo. - 2013. - № 1. - S. 104-107. DOI: 10.7256/1812 8696.2013.01.10.

20. S.F. Udartsev. Evolyutsiya idei evropeiskogo edinstva i opyt ee realizatsii v modelyakh gosudarstvennogo ustroistva // Pravo i politika. - 2012. - № 11. - S. 104-107.

21. O.I. Stavtseva. Dialog kul'tur na fone krizisa mul'tikul'turalizma // Filosofiya i kul'tura. - 2012. № 9. - S. 104-107.

22. G. G. Ershova. Antroposistema: kommunikativnye modeli i reguliruemaya integratsiya // Istoricheskii zhurnal: nauchnye issledovaniya. - 2012. - № 4. S. 104-107.

23. V.Ts. Khudaverdyan. Natsional'nye men'shinstva i immigranty v sisteme sotsial'nykh otnoshenii: sotsial'nofilosofskoe izmerenie // Filosofiya i kul'tura. - 2012. - № 7. - S. 104-107.

24. E. A. Popov. Etnicheskaya identifikatsiya v obshchestve posredstvom yazyka // Politika i Obshchestvo. - 2012. - № 3. - S. 104-107

25. Shchuplenkov N.O., Shchuplenkov O.V. Osobennosti razvitiya politiko-pravovoi orientatsii sotsialdemokraticheskogo dvizheniya v Rossii // NB: Istoricheskie issledovaniya. - 2014. - 2. - C. $22-77$. DOI: 10.7256/2306-420X.2014.2.10668. URL: http:// www.e-notabene.ru/hr/article_10668.html

26. Garifullina E.F. Razvitie chelovecheskogo kapitala kak innovatsionnoe napravlenie gosudarstvennoi politiki // NB: Ekonomika, trendy i upravlenie. - 2014. - 2. C. 36 - 43. DOI: 10.7256/2306-4595.2014.2.4544. URL: http://www.e-notabene.ru/etc/article_4544.html

27. Belkovets L.P. Inostrantsy v Sovetskoi Rossii (SSSR): regulirovanie pravovogo polozheniya i poryadka prebyvaniya (1917 - 1939-e gg.) Pervaya chast'. // NB: Voprosy prava i politiki. - 2013. - 5. - C. 296 - 350. DOI: 10.7256/2305-9699.2013.5.796. URL: http:// www.e-notabene.ru/lr/article_796.html

28. Belkovets L.P. Inostrantsy v Sovetskoi Rossii (SSSR): regulirovanie pravovogo polozheniya i poryadka prebyvaniya (1917 - 1939-e gg.) Vtoraya chast'. // NB: Voprosy prava i politiki. - 2013. - 6. - C. $220-284$. DOI: $10.7256 / 2305-9699.2013 .6 .808$. URL: http:// www.e-notabene.ru/lr/article_808.html 